\title{
Employee Empowerment at PT PLN UIP JBB
}

\author{
Djoko Pitoyo \\ Department of Industrial Engineering \\ Sangga Buana University \\ Bandung, Indonesia \\ djoko_pitoyo13@yahoo.com
}

\begin{abstract}
The purpose of this research is to find out the relationship between performance improvement through employee empowerment which is influenced by leadership and organizational culture factors in PT PLN Unit Induk Pengembangan Jawa Bagian Barat (UIP JBB). This study used the questionnaire method with respondents as many as 47 employees. The collected data was analyzed using path analysis, with the aim of knowing the relationship between variables. From the results of this study it was found that Leadership does not have a direct or indirect effect, through Employee Empowerment variables, significantly on Employee Performance. Organizational Culture has a significant direct influence on Employee Performance by 0.33 , and Organizational Culture has a significant indirect effect on Employee Performance through Employee Empowerment of 0.65. Employee Empowerment can be significantly influenced directly by the Organizational Culture variable of 0.64 . Employee performance can be directly influenced by Employee Empowerment variables of 0.49 .
\end{abstract}

Keywords - employee performance, employee empowerment, leadership, organizational culture

\section{INTRODUCTION}

The existence of a corporate company is usually determined by the performance of its organizational units. The performance of organizational units is obtained from the performance of its employees. Employee performance will influence how much they contribute work to the organization which includes: output quantity, output quality, output period, workplace presence, cooperative attitude (Mathis and Jackson, 2002). In other words, the performance of the employee itself determines the success or failure of the company in achieving the company's goals. If the performance begins to show a decline, it is certain that it is very difficult to reach the goal or even unable to reach the company's goals. Good performance is optimal performance, namely performance that matches the standards of the organization and supports the achievement of organizational goals.

In the company PT PLN in measuring the performance of each employee to the performance of organizational units each year using the KPI (key performance indicator) tool, where the achievement of each target is initiated from the top management to each of their subordinates. The portrait of the target trend and realization of PT PLN UIP JBB in 2015-2016. There is a gap between the target and the achievement that occurs (realization), where the overall gap ranges from $12 \%$. This is the problem at PT PLN UIP JBB where the performance of several organizational units has not been optimally influenced by employee performance.
For this reason, it is necessary to do a study to find out the factors that are influenced by the performance of organizational units at PT PLN UIP JBB.

To discuss this problem, management and organizational science approaches are used, specifically Human Resource Management and Organizational Behavior in solving these problems.

Performance problems certainly cannot be separated from the process, results and usability, in this case the performance is the work of quality and quantity achieved by an employee in carrying out his duties in accordance with the responsibilities that have been given to him. Good employee performance will directly affect performance institutions, and to improve employee performance certainly requires a long time and process. Assuming that the current PT PLN employees are the result of strict recruitment so that the ability factor and motivation factor are good enough, this performance research is discussed in organizational environmental factors, namely leadership, organizational culture and empowerment of work. On the basis of existing problems and several theoretical studies, it is necessary to do research on the influence of leadership, organizational culture through empowering employees that affect the performance of employees of PT PLN UIP JBB.

\section{RESEARCH METHODOLOGY}

Laten variables in this study are leadership (X1), organizational culture (X2), employee empowerment (M), and employee performance (Y). Uses sampling randomly, in accordance with Nazir (2003: 279) and Husein Umar (2004: 108). Respondents in this study were all employees PT. PLN UIP JBB that has a structural position at the supervisor level of 18 people and is added with employees who have more than five years work experience with a total of 47 employees.

Data collection methods used in this study were questionnaires and observations, and data analysis with Path Analysis. Path Analysis is an extension of multiple regression analysis, or path analysis is the use of regression analysis to estimate causality between previously defined variables based on theory (Ghozali, 2002). Path Analysis is intended to find out whether the relationship is caused by the direct and indirect influence of the exogenous variables variable on the dependent variable, the influence of the exogenous variable on the endogenous variables between leadership variables (X1) and organizational culture (X2) through employee empowerment (M) on performance variables $(\mathrm{Y})$. 
The research framework as :

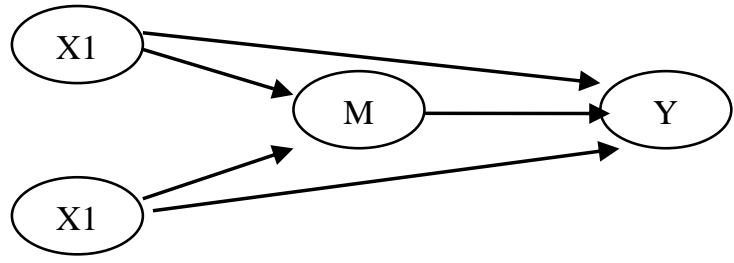

$\mathrm{Y}=\rho_{\mathrm{yx} 1} \mathrm{X}_{1}+\rho_{\mathrm{yx} 2} \mathrm{X}_{2}+\rho_{\mathrm{yxm}} \mathrm{M}_{+} \rho_{\mathrm{y}} \varepsilon$

Information:

$\mathrm{Y}=$ Employee Performance

$\rho \quad=$ endogenous variable path coefficient

$\varepsilon=$ error

$\mathrm{X} 1$ = Leadership

$\mathrm{X} 2$ = Organizational Culture

$\mathrm{M}=$ Empowerment of Employees

yx1 = coefficient of exogenous variable leadership

yx2 = Exogenous variable coefficient of organizational culture

yxm $=$ Exogenous variable coefficient empowerment of employees

Test equipment used in testing hypotheses using SPSS 16 software, regarding improving performance through employee empowerment which is influenced by leadership factors and organizational culture at PT PLN UIP JBB is the method of path analysis. The form of the equation is as follows:

$\underline{\text { Sub-structural equation } 1}=\mathrm{M}=b_{1} \mathrm{X}_{1}+b_{2} \mathrm{X}_{2+} \mathrm{e}_{1}$

Sub-structural equation $2=\mathrm{Y}=b_{1} \mathrm{X}_{1}+b_{2} \mathrm{X}_{2}+b_{\mathrm{m}} \mathrm{M}_{+} \mathrm{e}_{2}$

Information:

$\mathrm{Y}=$ Employee Performance

b1 = leadership regression coefficient

b2 = organizational culture regression coefficient

bm $=$ empowerment regression coefficient

$\varepsilon \quad=$ error

$\mathrm{X} 1$ = Leadership

$\mathrm{X} 2$ = Organizational Culture

$\mathrm{M}=$ Employee Empowerment

To justify the hypothesis test, a statistical test of the output produced by the path analysis model is used. Statistical tests include:

1) The coefficient of determination (R2) is essentially to measure the extent of the capability of the model in explaining the variation of the dependent variable. The coefficient of determination is ranging from zero to one.

2) The t test is done by comparing the difference between the values of the two average values with the standard error of the difference in the average of two samples (Ghozali, 2011: 98-99)
The F test basically shows whether all the independent or free variables included in the model have a joint or simultaneous influence on the dependent variable or bound. If the value of $\mathrm{F}$ is greater than 4 then Ho can be rejected at a $5 \%$ confidence level in other words stating that the independent variable simultaneously and significantly affects the dependent variable and compares the $\mathrm{F}$ value of the calculation results with the $\mathrm{F}$ value according to the table. If the value of $F$ count is greater than the value of $F$ table, then Ho is rejected and accepts Ha (Ghozali, 2011: 98).

\section{RESEARCH RESULT}

In this method the researcher analyzes each value of the variables consisting of leadership (X1), organizational culture (X2), employee empowerment (M), and employee performance $(\mathrm{Y})$, analysis is carried out using the percentage of the interval scale assessment as follows:

\section{A. Leadership (X1)}

From 16 questions consisting of 8 indicators such as being fair, giving suggestions, supporting achieving goals, as a catalyst, creating a sense of security, as a representative of the organization, a source of inspiration, and being respectful. In the leadership variables, hat $27 \%$ of respondents stated Strongly Agree (SS), 64\% of respondents stated Agree (S), and $8 \%$ of respondents stated Lack of Agree (KS). Dimensions give suggestions worth $83 \%$, dimensions support the achievement of goals worth $84 \%$, dimensions as catalysts are worth $82 \%$, dimensions of creating security are $82 \%$, dimensions as representative of organizations are $86 \%$, dimensions of inspiration are $84 \%$, and the dimension of respect is $83 \%$. From the results of the leadership questionnaire the value of $3139 / 3760=83 \%$ or Good category was obtained.

\section{B. Organizational Culture (X2)}

From 14 questions consisting of 7 indicators such as innovation and risk taking, attention to detail, outcome orientation, people orientation, team orientation, aggressiveness, and stability showed that $26 \%$ of respondents said that they were very agree (SS), 63\% of respondents stated Agree (S ), and $11 \%$ of respondents stated Lack of Agree (KS). The dimensions of innovation and risk taking are worth $80 \%$, the dimensions of attention to detail are $84 \%$, the dimensions of the outcome orientation are $85 \%$, the dimensions of the people orientation are $82 \%$, the dimensions of the team orientation are $84 \%$, the dimensions of aggressiveness are $83 \%$, and the dimensions of stability are $83 \%$. The results of the organizational culture questionnaire obtained values of $2729 / 3290=83 \%$ or categorized as Good.

\section{Employee Empowerment (M)}

From 12 questions consisting of 4 indicators such as trust, meaningfulness, autonomy, and impact showed that as many as $20 \%$ of respondents stated Strongly Agree (SS), 68\% of respondents stated Agree (S), and $12 \%$ of respondents stated Lack of Agree (KS). The trust dimension is $82 \%$, the dimension of meaningfulness is $82 \%$, the autonomous dimension is $80 \%$, and the impact dimension is $81 \%$. The results of the employee empowerment questionnaire obtained a value of $2291 / 2820=81 \%$ or Good category. 


\section{Employee Performance $(Y)$}

From 12 questions consisting of 7 indicators such as work quality, work quantity, knowledge, work adjustments, reliability, work relations, and work safety, $12 \%$ of respondents stated Strongly Agree (SS), 69\% of respondents stated Agree (S), and $18 \%$ of respondents stated Lack of Agree (KS), and $1 \%$ of respondents stated Disagree (TS). Dimension of work quality is $79 \%$, dimension of work quantity is $75 \%$, dimension of knowledge is $74 \%$, dimension of adjustment is $82 \%$, dimension of reliability is worth $79 \%$, the employment relationship dimension is $81 \%$, and the occupational safety dimension is $80 \%$. From the results of employee performance questionnaires obtained values of $2587 / 3290=79 \%$ or Good category.

\section{Path Analysis}

1) Analysis of the influence of leadership and organizational culture on employee empowerment. The value of $\mathrm{R} 2$ ( $\mathrm{R}$ Square) of 0.284 . $\mathrm{R} 2$ is used to calculate the residual value $\mathrm{e} 1$. Where $\mathrm{e} 1$ is a variant of employee empowerment variables which is not explained by leadership and organizational culture variables.

$\mathrm{e} 1=\sqrt{\left(1-R^{2}\right)=} \sqrt{1-0,284}=\sqrt{0,716}=0,846$

$\mathrm{M}=\mathrm{b}_{1} \mathrm{X}_{1}+\mathrm{b}_{2} \mathrm{X}_{2}+\mathrm{e}_{1}$

\section{$M=-0,246 X_{1}+0,641 X_{2}+0,846$}

The equation explains that whenever there is an increase in leadership quality there will be a decrease in employee empowerment of 0.246 units assuming other independent variables are considered constant. Then, whenever there is an increase in the quality of organizational culture, there will be an increase in employee empowerment of 0.641 units. In general, from the above equation it can be concluded that if leadership and / or organizational culture experience quality improvement, employee empowerment will also increase as well.

2) Analysis of the influence of leadership, organizational culture, and employee empowerment on employee performance shows the value of R2 ( $R$ Square) of 0.606 . $\mathrm{R} 2$ is used to calculate the residual value of $\mathrm{e} 2$. Where e2 is a variable variant of employee performance that is not explained by variables of leadership, organizational culture, and employee empowerment.

$\mathrm{e}_{2}=$

$\sqrt{\left(1-R^{2}\right)}=\sqrt{1-0,606}=\sqrt{0,394}=0,627$

$\mathrm{Y}=\mathrm{b}_{1} \mathrm{X}_{1}+\mathrm{b}_{2} \mathrm{X}_{2}+\mathrm{b}_{\mathrm{m}} \mathrm{M}+\mathrm{e}_{2}$

\section{$Y=0,119 X_{1}+0,339 X_{2}+0,497 M+0,627$}

The equation explains that whenever there is an increase in leadership quality there will be an increase in employee performance by 0.119 units assuming the other independent variables are constant. Then, whenever there is an increase in the quality of organizational culture, there will be an increase in employee performance by 0.339 units. Furthermore, whenever there is an increase in the quality of employee empowerment, there will be an increase in employee performance of 0.497 units.

In general, from the above equation it can be concluded that if leadership and / or organizational culture and or employee empowerment experience an increase in quality, employee performance will also increase as well

\section{CONCLUSIONS AND RECOMMENDATIONS}

From the results of the analysis and discussion that have been carried out, the conclusions can be taken as follows:

1) Leadership does not significantly influence employee empowerment at PT PLN UIP JBB, where the negative path coefficient value is equal to -0.246 and significance 0.127 which is greater than $\alpha(0.127>0.05)$. The lower the intensity of leadership, the lower the employee's performance.

2) Organizational culture has a significant influence on employee empowerment of 0.641 and a significance of 0 which is smaller than $\alpha(0<0.05)$. This means that if there is an increase in the quality of organizational culture, the empowerment of employees will increase by 0.641 .

3) Leadership does not have a significant effect on employee performance directly at 0.119 and significance of 0.335 which is greater than $(0.335>0.05)$. Therefore it can be concluded that even though it has a positive path coefficient but its effect is not significant.

4) Organizational culture has a significant direct influence on employee performance by 0.339 , as well as significance of 0.019 which is smaller than $\alpha(0.019$ $<0.05)$. Therefore it was concluded that there was a positive and significant influence of organizational culture on employee performance of 0.339 .

5) The performance of PLN UIP JBB employees can be directly affected by employee empowerment variables with the equation $\mathrm{M}=>\mathrm{Y}=\rho \mathrm{mm}=0.497$. This means that if there is an increase in the quality of employee empowerment, the performance of PLN UIP JBB employees will increase by 0.497 .

The suggestions that can be put forward in this study are as follows:

1) Communication needs to be improved between the top management and the employees of the PLN UIP JBB through media suggestion boxes, coffee mornings, employee gatherings, and joint sports or events that can be held together which do not discuss work.

2) To reduce weakness in leadership variables, structural officials and senior employees must provide good examples to other employees.

3) PLN employees UIP JBB need to be facilitated by PLN management in terms of 7 performance indicators such as work quality, work quantity, knowledge, work 
adjustments, reliability, work relations, and work safety where the results of the questionnaire assessment have only reached $79 \%$. With the establishment of good industrial relations between management and employees is expected to be a positive value that can generate employee performance.

Exogenous factors can be explored more deeply from other variables such as work environment, job satisfaction, and the influence of the position so that it can be explained in the influence on the performance of PLN UIP JBB employees for subsequent research.

\section{REFERENCES}

[1] Mathis, Rober. and Jackson, John. Manajemen Sumber Daya Manusia. : Salemba empat. Jakarta, 2002.

[2] Nazir, Moh. Metode Penelitian. Ghalia Indonesia. Jakarta. 2003.

[3] Umar, Husein. Manajemen Sumber Daya Manusia dan Organisasi. Gramedia Pustaka Utama. Jakarta. 2004

[4] Ghozali, Imam. Aplikasi Analisis Multivariate Dengan Program SPSS. Badan Penerbit Universitas Diponegoro. Semarang. 2002.

[5] J. Miner, John B. Industrial Organizational Psychology.: Mc GrawHill Inc. Singapore. 1992,

[6] Thoha, Mftah. Kepemimpinan Dalam Manajemen. Raja Grafindo Persada. Jakarta. 2010. 